\title{
Fernando I and Alfonso VI as Patrons of the Arts
}

\author{
John WiLliams
}

The exclusive reference to males in the title is not meant to discount the more than significant role played by the female side of the Leonese royal families. In terms of direct patronage it is indeed easier to verify roles for queens and infantas than for Fernando and Alfonso. This is especially true for the reign of Alfonso. The Master, Don Manuel Gómez-Moreno, noted the dominant role rulers played in peninsular patronage, and commented expressly on the fact that recibieron inspiraciones todos ellos de sus respectivas mujeres $y$ hermanas... ${ }^{I}$ What follows is an attempt to broadly compare the patterns of patronage from mid-eleventh to the beginning of the twelfth century, with the names Fernando and Alfonso identifying the successive rules within this period. The names of Sancha and Urraca will figure prominently. Perhaps the virtual loss of Sahagún has obscured another name that might have been included, Constanza, but that remains mere speculation.

Royal patronage had been significant in pre-Romanesque Spain, as the splendid treasuries of the Asturian rulers bear witness. If there was an era when one might claim monastic patronage dominated, it was during the tenth century, when the Commentary on the Apocalypse by Beatus became a sine qua non for the libraries of monasteries found along the frontier with al-Andalus. The result was the brilliant art-historical chapter we entitle "Mozarabic Painting". The first work we can assign to the patronage of Fernando and Sancha continues that tradition, its royal sponsorship breaking what had been an exclusively monastic enterprise. ${ }^{2}$ The Commentary they commissioned in 1047 proclaimed its origin in an elegant acrostic (f. 7): FREDENANDUS REX DEI GRA[TIA] M[EMO]R[I]A LIBER/SANCIA M[EMO]R[I]A L[I]BRI]. ${ }^{3}$ Its elevated patronage is reflected in the elegance of materials, the liberal use of purple, silver and gold, and a refined technique in writing and illumination. This refine-

1 M. Gómez Moreno, Arte románico, esquema de un libro, Madrid, 1934, p. 8.

2 The only other copy of the Commentary of Beatus for which royal intervention is a certainty is that apparently commissioned by Queen Berenguela of Castilla around 1220 and now in the Pierpont Morgan Library (M. 429). See D. RaIzman, "Prayer, Patronage, and Piety at Las Huelgas: New Observations on the Later Morgan Beatus," in Church, State, Vellum, and Stone, ed. T. MARTIN and J. HARrIs, Leiden-Boston, 2005, pp. 235-273.

3 Madrid, BN, Vit. 14-2. See J. Williams, The Illustrated Beatus: A Corpus of the Illustrations of the Commentary, III, London, 1998, pp. 34-40; M. SÁnChez Mariana and J. Yarza LuACES, El beato de Liébana: códice de Fernando I y doña Sancha, Barcelona, 1994. 
ment is especially noticeable in the illumination of the prefatory imagery like the Alpha frontispiece (fol. 6r), and the Evangelist/Gospel Pages (fols. 7v-10r). There are hints, as well, of a different mode of designing drapery patterns, with a structure that would become routine in Romanesque illumination (fig. 1). Despite its refinement and hints of a progressive style it is a copy clearly within the Mozarabic tradition established by Maius of Tábara in the middle of the tenth century. ${ }^{4}$ Whether or not the powerfully expressive, anti-classical Mozarabic style that embodied in an ideal way the events of the Apocalypse was due to monastic, as opposed to royal, patronage is debatable, but the loss of expressive power in the post-Mozarabic copies is hard to ignore. It was a price paid for a cultural reorientation.

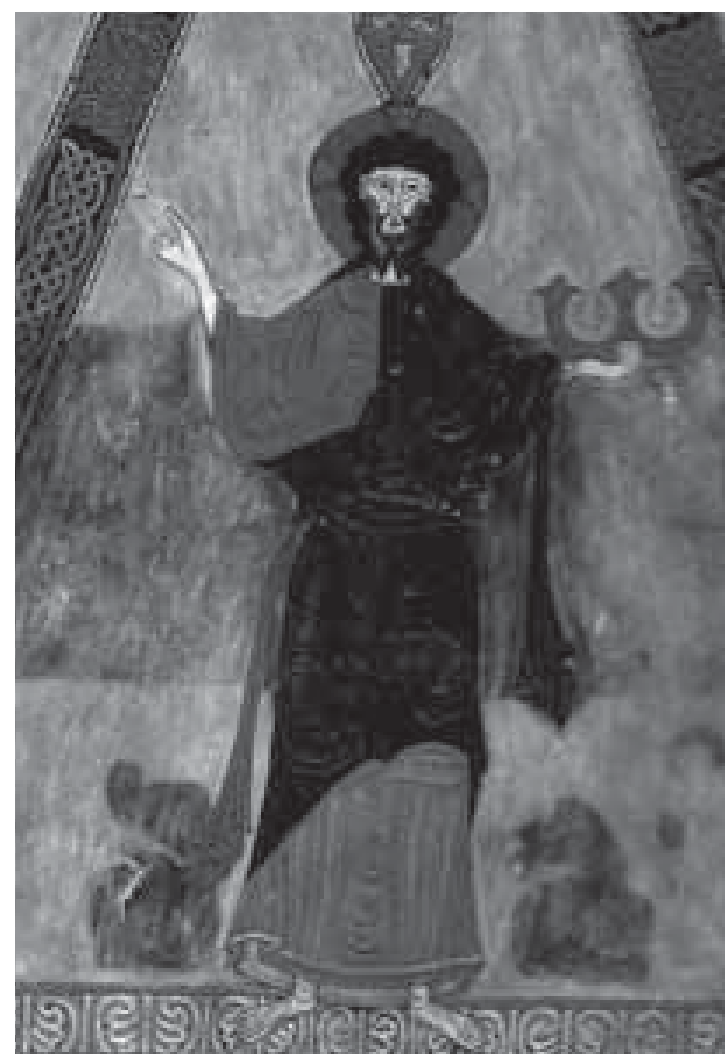

If this reorientation is only hinted at in Facundus's Commentary, most markedly in the figure of Christ of the Alpha page (fig. 1), the next book linked to the royal pair is so marked by a new aesthetic as to defy easy explanation. It is the "Diurnal" today in Santiago (Bibl. Universitaria, Ms. 609, Res. 1). ${ }^{5}$ The advance may be seen in a comparison of the Christ figure of the Alpha of 1047, with that of the Alpha of the Diurnal (fig. 2), where wind-blown drapery, a hallmark of the emerging Romanesque style, distinguishes the figure of the standing Christ. This prayer book, comprising a Psalter and a Book of Canticles, is nothing short of paradigmatic as a witness to the Leonese ideal of royal patronage. The conditions of patronage are spelled out in an elaborate acrostic page at the beginning: FREDINANDI REGIS SUM LIBER NECNON ET SANCIA REGINA. ${ }^{6}$ The

Fig. 1. Alpha (detail), Madrid, BN, Cod. 14-2, fol. 6r.

4 J. Williams, Illustrated Beatus, I, London, 1994, pp. $61 \mathrm{ff}$.

5 M. DíAz y DíAz, "El códice de Compostela. Tradición y modernidad", in Libro de Horas de Fernando I de León, Edición facsimil do manuscrito 609 (Res. 1) de la Biblioteca Universitaria de Santiago de Compostela, Madrid, 1995, pp. 11-51; S. MoraleJo, "Notas a la ilustración del Libro de Horas de Fernando I," Ibid., pp. 55-63 (Patrimonio artístico de Galicia y otros estudios. Homenaje al prof. Dr. Serafin Moralejo Álvarez, ed. A. Franco Mata, 3 vols., Santiago de Compostela, 2004, II, pp. 311-316 [en adelante, PAG]); T. Martin, Queen as King: Politics and Architectural Propaganda in Twelfth-Century Spain, Leiden-Boston, 2006, pp. 58-59.

6 M. Díaz y Díaz, Códices visigóticas de la monarquía leonesa, León, 1983, pp. 283-284. 
colophon at the end (fol. 208r) recounts in detail the circumstances of production: Sancia ceu voluit / quod sum regina peregit / era millena nouies / dena quoque terna / Petrus erat scriptor / Fructosus denique pictor. Thus the book was undertaken at the initiative of Queen Sancha in AD 1055, but belongs to Fernando and Sancha, Petrus being the scribe, Fructuosus the illuminator. ${ }^{7}$ This information is communicated pictorially (fol. $3 \mathrm{v}$ ) in an extraordinarily precise way, as if it were a record of a tableau vivant (fig. 3). Fernando, crowned, holding a scepter and, as in real life, red-headed, ${ }^{8}$ salutes Sancha who stands at his left on the other side of the pictorial space. Between them is a figure that seems to be directed to cross this space by Sancha and surrender the Book of Hours to her consort, Fernando, thus recapitulating the process outlined in the colophon of $208 \mathrm{v}$.

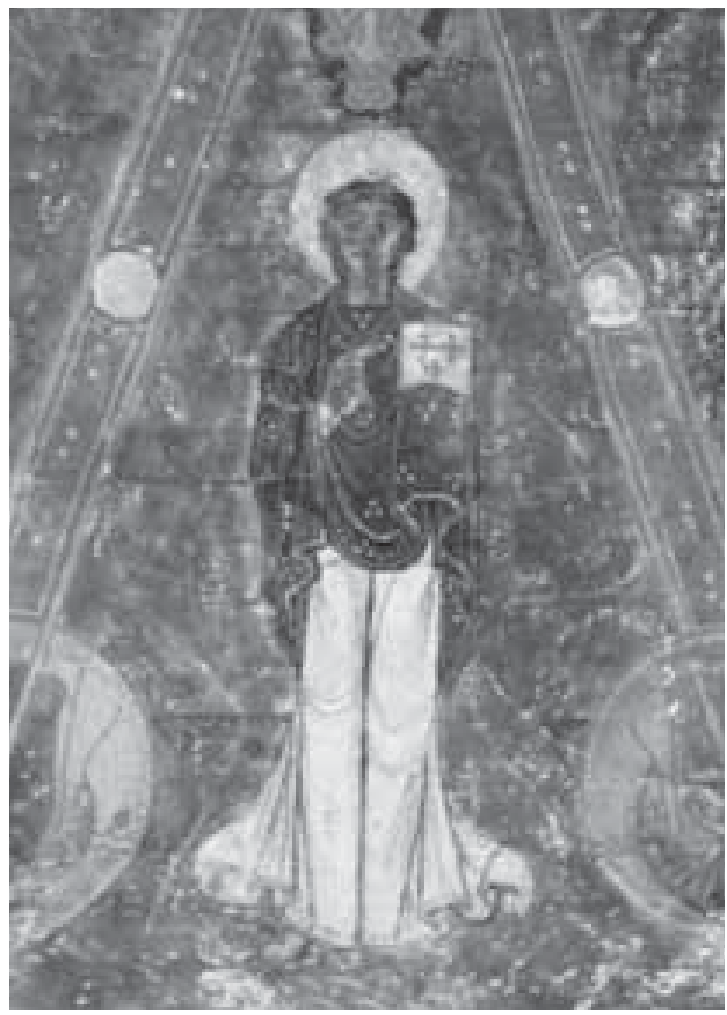

Fig. 2. Alpha, Santiago de Compostela, Biblioteca Universitaria, Ms. 609 (Res. 1), fol. 1r. (detail)

The extraordinary luxury of this Book of Hours is apparent at all turns. The vellum is virtually without blemish and creamy white. As has been noticed, purple and gold, generously applied, point toward imperial honor. Just how such a stylistic revolution was managed is far from clear, but in terms of motive it is useful to note that it coincided with a new stage of Leonese ascendancy. ${ }^{9}$ From the time of Alfonso III the imperial title had been applied to the kings of León. In marrying Sancha, heir to the Leonese throne, Fernando had assumed the same

7 Although A. López Ferreiro failed to see that the first "u" of the name formed a nexus with the preceding $\mathrm{r}$ and read the name of the painter as Frictosus (Historia de la Santa A.M. Iglesia de Santiago de Compostela, II, Santiago de Compostela, 1899, pp. 524-26), it has been assumed by most that the painter's name was Fructuosus. DíAz y DíAz noted that the need to maintain an hexameter form for the poetic colophon required the shortening of the name to Fructosus ("El códice de Compostela", p. 47).

8 M. Encina Prada Marcos and J. M. Vidal Encinas, "Arqueo-Antropología del Panteón Real de San Isidoro de León,” in Monarquía y sociedad en el reino de León: de Alfonso III a Alfonso VII, León, 2007, II, pp. 599-688, at 677.

9 M. CAstiñEIras Gonzalez, "Algunos usos y funciones de la imagen en la miniatura hispánica del siglo XI: los Libros de Horas de Fernando I y Sancha," in Propaganda y poder (Congreso penínsular de Historia de Arte, 5-8 maio 1999), Lisboa, 2000, pp. 71-94. 


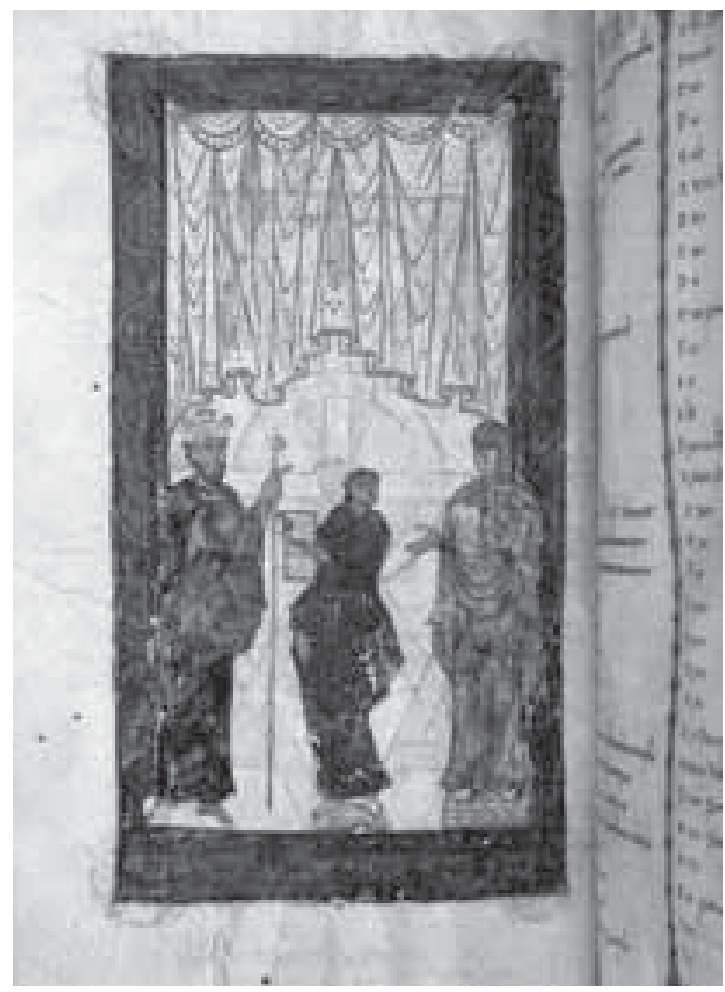

Fig. 3. Dedication frontispiece, Santiago, Biblioteca Universitaria Ms. 609 (Res.1), fol. 3v.

dignity. His "consecration" and "anointment" as such had occurred almost two decades earlier in $1037 . .^{10}$ But on 1 September 1054 Fernando defeated his brother García and his Moorish allies at Atapuerca. Along with the recovery of Castilla Vieja, territory Fernando had ceded to García for his help against Vermudo III, Fernando gained La Bureba and a good part of Montes de Oca. It was a crowning moment. Without rivals, Fernando could begin a march on the wealthy cities of Andalucía, usually with Sancha at his side. In the same year that he received this book of hours from his Queen, Fernando convened a grand Council in Coyanza with the motive of reforming the church, even as the pre-Conquest rulers had. ${ }^{11}$ Indeed, for Marius Férotin it was comme le dernier echo des grands conciles nationaux de Tolède. ${ }^{12}$ Serafín Moralejo rightly concluded that no es casualidad por lo que el códice se fecha en 1055, un año después de la victoria de Atapuerca, que supuso para Fernando la plena asunción de la idea imperial leonesa..${ }^{13}$ It may not be coincidental that the formula for the full-page Presentation frontispiece featuring a completed book being offered to its royal sponsor was not peninsular, but of a type popular in imperial circles north of the Pyrenees,${ }^{14}$ but it is so extraordinary in design as to make the requirement of a model problematic. The special

10 On the history of regal anointment in the peninsula see P. LineHAN, History and Historians of Medieval Spain, Oxford, 1993, pp. 128ff.

11 A. García Gallo, "El concilio de Coyanza", in Anuario de historia del derecho español, 20 (1950), pp. 275-633. On the relative merit of the two surviving redactions of the acts of the council see LINEHAN, History, pp. 184-188.

12 M. Ferotin, "Deux manuscripts wisigothique de la bibliothèque de Ferdinand I", Bibliothèque de l'Ecole de chartes, 62 (1901), pp. 374-387, at 374.

13 S. Moralejo, "Artistas, patronos y público en el arte del camino de Santiago", Compostellanum, XXX (1985), pp. 395-430, at 410 [=PAG, II, p. 29].

14 J. Prochno, Das Schreiber- und-Dedikationsbild in der deutschen Buchmalerei, 800-1100, Leipzig and Berlin, 1929, pls. 2, 6, 7, and passim. 
nature of this prayer book destined for Fernando is evident from the routine, even antiquated, character of the prayer book for Sancha's use that was completed in $1059,{ }^{15}$ or of the equally conservative copy of the Etymologies, copied in 1047 for Sancha and her son Sancho and now in the Escorial. ${ }^{16}$

The Presentation frontispiece is, however, far from a replica of any scene known to us and subject to dispute as to just whom the intermediary figure might be. Most often he is recognized as Petrus, the scribe, or as Fructuosus the painter, or an amalgam of the two. ${ }^{17}$ Angel Sicart rejected these possibilities and proposed that he was a lay figure, a noble of the court, perhaps, who had played a role in the confection of the manuscript, a conclusion that appealed to Díaz y Díaz. ${ }^{18}$ In this line Prado-Vilar has recognized the figure as the son of Fernando and Sancha, the future Alfonso VI of León:

Aunque parezca plausible a primera vista [the identification of the figure as Petrus or Fructuosus], esta interpretación se cae por su propio peso ante un simple análisis formal de la miniatura. Dicha figura luce ropajes reales, idénticos a los que viste el monarca, y se muestra descalza, siguiendo una fórmula ritual. Su menor estatura no viene dictada por la escala jerárquica, que contradiría las premisas estilísticas de un manuscrito que de forma tan clara hace ostentación de su nuevo estilo naturalista, sino que se refiere a la edad del personaje, subrayada por su rostro y la expresión inocente con la que mira hacia Sancha. ${ }^{19}$

Prado-Vilar was right to challenge my earlier claim that the dress of this intermediary figure differed from that of the king. ${ }^{20}$ They are similarly attired. The assumption that they wear ropajes reales is, however, debatable. Actual regal attire is represented in two portraits of Fernando on the Arca of San Isidoro of the treasury of San Isidoro, one on the lid (fig. 4), another on one of the long sides (fig. 5). ${ }^{21}$ On the lid Fernando is, it would seem, accompanied by Alfonso and the other sons, all resembling the king. In the relief on the side Fernando

15 Salamanca, Bibl. Universitaria Ms. 2668. See CastiñEIRAs, “Algunos usos”, pp. 89-94; F. GalvÁN FreILE, “El 'Liber Canticorum et Horarum' de Sancha (B.G.U.S., MS. 2668): entre la tradición prerrománica y la modernidad", in Hispaniens norden im 11. Jahrhundert. Christliche Kunst im Umbruch, ed. A. ArBEITER, C. Kothe, B. Marten, Petersberg, 2009, pp. 248-256.

16 Cod. \&.I.13, Díaz y Díaz, Códices visigóticos, p. 383.

17 J. Williams, "Prayer Book of Ferdinand and Sancha", in The Art of Medieval Spain a.d. 500-1200, New York, 1993, pp. 290-291.

18 A. Sicart, Pintura Medieval: La miniatura, Santigo de Compostela, 1981, pp. 30-33; DíAz y DíAz, Códices, pp. 282; ID., "Códice de Compostela", p. 47.

19 F. Prado-Vilar, “Lacrimae rerum: San Isidoro de León y la memoria del padre,” Goya, 328 (2009), pp. 195-221, at 205 .

20 Williams, "Prayer Book".

21 In a revision of his original assumption that the Arca was a work of around 1063 in "El Arca de las reliquias de San Isidoro", Archivo español de arte y arqueología, VII (1932), pp. 205-212, M. GóMEz MoRENO later identified the casket, without discussion, as a work of Fernando's father, Sancho III, with portraits of Sancho and his sons, as well as a representation of Sancho's father, García el Trémulo, entombed (En torno al crucifijo de los reyes Fernando y Sancha, Valencia, 1965, pp. 7-8). 


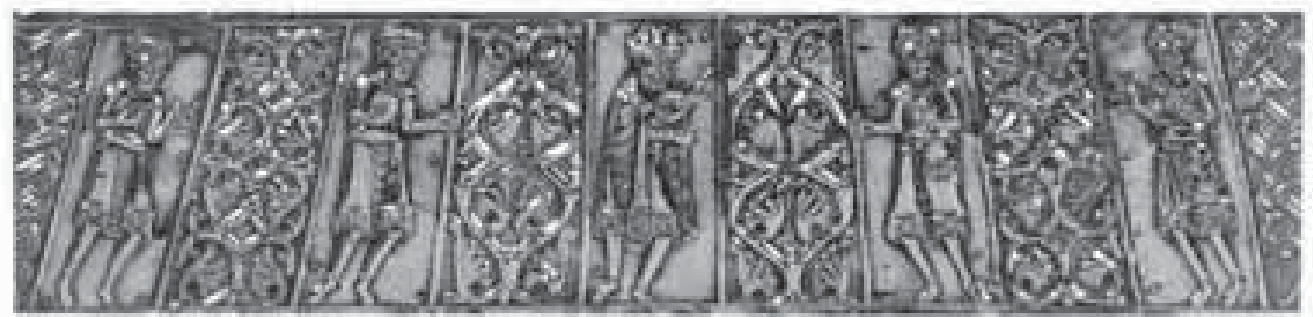

Fig. 4. Reliquary of San Isidoro, León, Colegiata de San Isidoro, detail of lid.

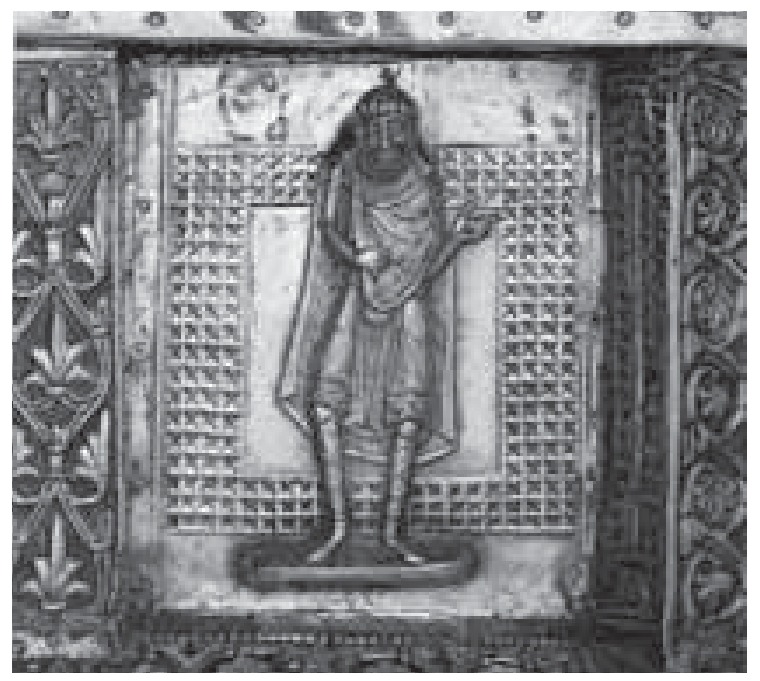

Fig. 5. Reliquary of San Isidoro, León, Colegiata de San Isidoro, Fernando. stands alone, without a crown, in penitential mode. In both images on the Arca the king is dressed in a tunic, with a mantel fastened at the shoulder. His legs are covered by laced leggings that reach to the knee. It might be thought that the German artist responsible for the reliquary might have used a formula unrelated to Leonese use, but it is the one used slightly later for the figure of Fernando kneeling at the Crucifix painted on the walls of the Panteón, and in the contemporary Privilegio de Nájera Fernando's brother, García III of Navarra, is similarly dressed..$^{22}$ The masculine figures of the presentation page may be comparably dressed, but not in the ropajes reales currently in fashion.

His extraordinary position at the center of the composition as well as his untonsured head has been seen as reason to reject an identity for the central figure as either scribe or artist. The first objection loses some force when the extraordinary nature of the frontispiece as a reprise of the production and use of the book is taken into account. Moreover, in the great conciliar manuscript of the tenth century from Albelda clerics are depicted unshorn and untonsured..$^{23}$ There is an alternative identification still more attractive, however. In dress as well as gesture and crown the image of king

22 Gómez Moreno, Arte románico, lam. VI.

23 Escorial, Bibl. del Monasterio, Cod. d.I.2. See S. de Silva y VerÁstegui, Iconografía del siglo X en el reino de Pamplona-Nájera, Pamplona, 1984, lams. XX, XXII. 
David (fig. 6) at the head of penitential Psalm XXX (fol. 29v), ${ }^{24}$ replicates the figure of Fernando, with the exception that Fernando is wearing shoes, and it is difficult to avoid the conclusion that the Leonese king has forsaken his normal regalia in order to appear in robes identifying him with a biblical king. Joaquín Yarza preferred to recognize this barefoot central figure as David, the author of the Psalms and kingly model, and therefore as worthy of such an exalted position. ${ }^{25}$ Although the performance he is engaged in might seem unfitting for the biblical David, this identification is attractive. However, the manner of his participation as a book-bearing link between the royal couple so perfectly matches the colophon's record of the book's context that it cannot entirely eliminate his identity as Petrus/Fructuosus. And probably the latter, for in the colophon, which identifies Petrus with a typical designation as scriptor, Fructuoso is entitled pictor. Díaz y Díaz held this title to be unique, ${ }^{26}$ but in fact, there is a precedent from a century earlier: Maius of Tábara was termed arcipictor in a colophon by his disciple, Emeterius. ${ }^{27}$ This unique distinction was well deserved, for it was Maius who converted the original pictorial content of the Commentary on the Apocalypse of

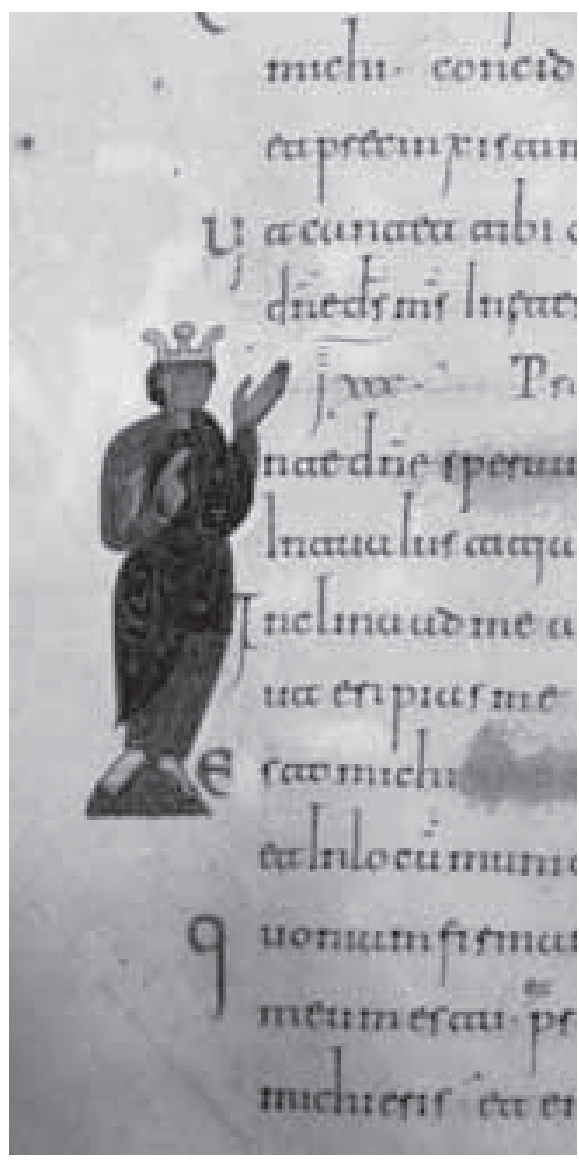

Fig. 6. David, Santiago de Compostela, Biblioteca Universitaria, Ms. 609 (Res. 1), fol. 29v.

Beatus into the richly endowed format we associate with the Commentary today. If the colophon of Fernando's Book of Hours reached beyond the normal to honor the special talent of Fructuosus as pictor, such recognition may have justified a special prominence in the frontispiece as well. In any case, it is difficult to imagine prince Alfonso in such a guise, shoeless and so robed, or, indeed, Sancho, who as Fernando's eldest son might have taken precedence over the fifteen year-old Alfonso. In the Privilegio de Nájera, the charter of 1052-1054 whereby the Navarrese king founds and endows the monastery of Santa María de Nájera, García speaks in first person and

\footnotetext{
24 M. CAstiñEIRAs, "Algunos usos”, pp. 76-77.

25 J. YARZA, Arte y arquitectura en España 500-1250, 6 ${ }^{\text {th }}$ ed. Madrid, 1990, pp. 167-8, 357, n. 17 bis.

26 M. DíAz y DíAz, "Códice de Compostela", p. 47.

27 J. Williams, Illustrated Beatus, II, pp. 43-45.
} 
recounts the Old Testament's record of royal largesse, especially that of Solomon, son of David, in the service of the Lord:

Y si los hijos de esta [la exhausta Sinagoga] fueron obligados a edificar con todo cuidado y grande aparato y copia de riquezas suntuosamente el tabernáculo y templo de Jehová; con mucho mas razón estamos obligados los hijos de la nueva Libertad á trabajar en la Casa del Señor y á dotar maravillosamente con ricos dones la Iglesia, fabricada con la sangre del Redentor, salida de su sacro costado. ${ }^{28}$

Assuming the role as mecenas indicated by his Old Testament ancestors, a list of gifts follows. Fernando was the first to witness the charter. We may imagine that in the following year Fernando, in the context of a book of prayers rather than a record of material benefaction, assumed the role of David, the psalmist king.

Stylistically the Book of Hours remains something of an enigma. The Presentation frontispiece is a remarkable page in a remarkable book. In contrast to the brilliant Mozarabic book art, brown and dark blue dominate. All participants are rendered in a way that emphasizes their bulk and actual or possible movement in contrast to the static nature of Mozarabic figures. Indeed, contrapposto is part of the strategy of story telling. And as a bonus an ingeniously designed and carefully rendered curtain offers a stunning affirmation that a third dimension can be easily evoked in pictorial narratives. Gómez-Moreno compared the precocious new style to that of the Beatus of the Gascon monastery of Saint-Sever-sur-1'Adour, ${ }^{29}$ a comparison endorsed subsequently. ${ }^{30}$ It is true, as well, that the most immediate or confirmable links to the ecclesiastical culture north of the Pyrenees fostered by Fernando involved southern France, namely the cult of San Antoninus (San Antolín), centered at Fredelas. His feast day appears in the Diurnal. ${ }^{31}$

Still closer in style to those of the Diurnal are the figures of the Privilegio de Nájera (fig. 7). ${ }^{32}$ As with the Diurnal, the Privilegio has not been anchored to a particular scriptorium. Díaz y Díaz concluded that the Diurnal must have been executed by

28 F. FitA, "Santa María la Real de Nájera. Estudio crítico," Boletín de la Real Academia de la Historia, 26 (1895), pp. 155-198, at 177.

29 M. Gómez Moreno, Arte románico, pp. 17-18.

30 J. Williams, «Le Beatus de Saint-Sever: état des questions", in Saint-Sever, Millénaire de l'abbaye (Colloque international 25, 26 et 27 mai, 1985), ed. J. CABANOT, Mont-de-Marsan, 1986, pp. 251-263; SiCART, Pintura medieval, pp.35-37.

31 C. J. Bishкo, "Fernando I y los orígenes de la alianza castellana-leonesa con Cluny", Cuadernos de historia de España, XLVII-XLVIII (1968), pp. 31-135, at 49-50. In English in Bishko, Studies in Medieval Spanish Frontier History, London, 1980, Study II, pp. 10-14.

32 Real Academia de la Historia. See S. Silva y Verástegui, "La miniatura en el reino de PamplonaNájera (905-1076)", in García Sánchez III "El de Nájera”. Un rey y un reino en la Europa del siglo XI, Logroño, 2005, pp. 327-365, at 362-365; F. Galván Freile, "Documento de la Fundación del monasterio de Santa María de Nájera”, in Sancho el Mayor y sus herederos, dir. I. BANGo Torviso, Pamplona, 2006, vol. I, pp. 287-290. Galván considered the possibility that it may be a copy of the twelfth century. 

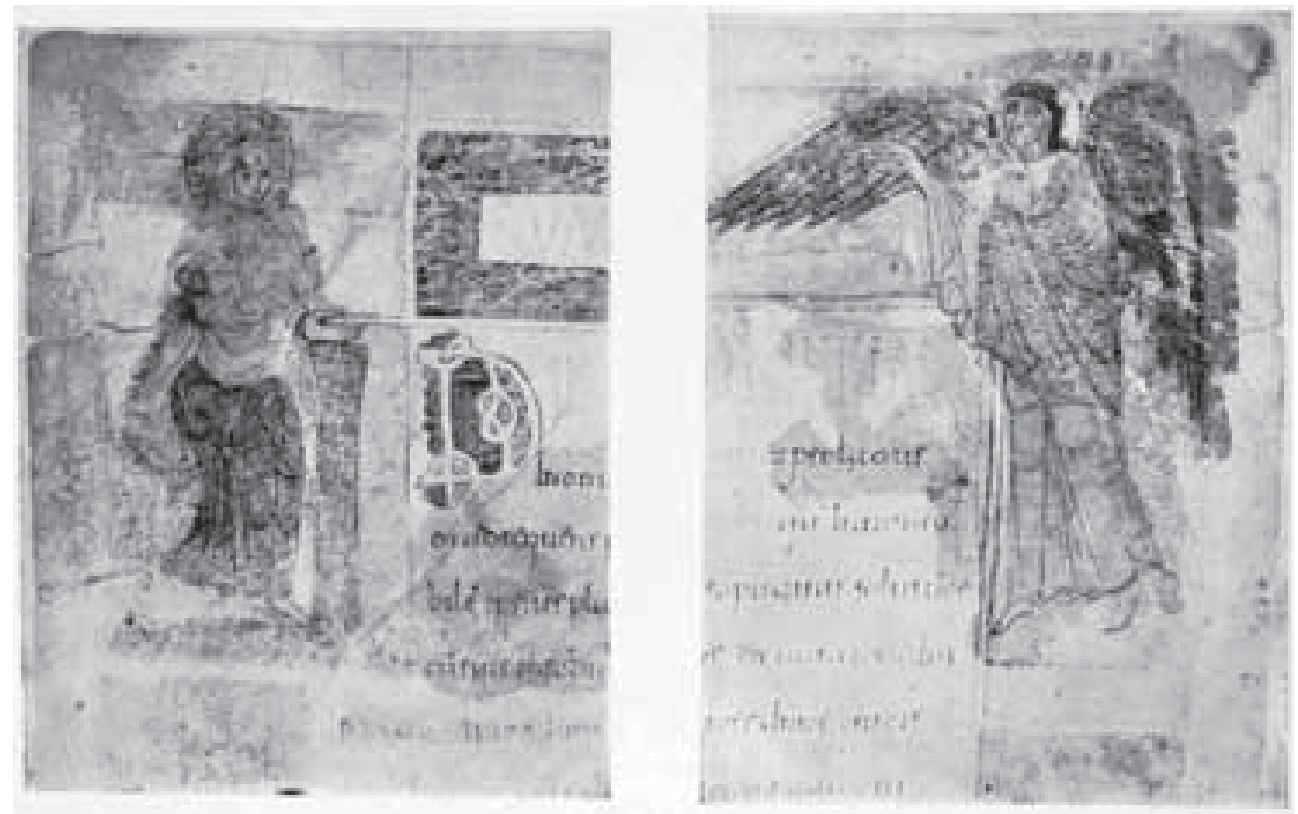

Fig. 7. Annunciation, Privilegio de Nájera, Madrid, Real Academia de la Historia.

Fructuosus in a monastery with a particularly well-endowed library and a tradition of illuminating books. ${ }^{33}$ If the Privilegio is considered a clue to the Diurnal's origin, San Millán de la Cogolla must be one of the few candidates for such a site, for it was only a day's journey from Nájera. It is true that San Millán's illuminated books before the time of the Privilegio, though numerous, do not forecast its specific style. The bestknown Romanesque style associated with San Millán, the miniatures that completed the Beatus of San Millán ${ }^{34}$ and the Missal of San Millán (fig. 8) are from around 1100. These display a Byzantinizing style imported, surely, from across the Pyrenees, and the different hands that produced them confirm that this active center had multiple currents to tap. Their failure to come closer to the actual style of the Diurnal and the Privilegio would be attributable to the more than six decades that separate them from the Diurnal and the Privilegio. ${ }^{35}$ Although Díaz y Díaz did not attempt to link Fructuosus to San Millán, in his analysis of the text of the Diurnal, he frequently cited

33 "Códice de Compostela", pp. 49-50. He proposed Silos as the place of Petrus's formation, but as A. BoYLAN demonstrated, it is highly unlikely that Silos had a scriptorium before the end of the eleventh century ("The Silos Beatus and the Silos Scriptorium", in Church, State, Vellum, and Stone, Leiden-Boston, 2005, pp. 173-205). For his qualified acceptance of a scriptorium at Silos see M. DíAz y Díaz, "El escriptorio de Silos", Revista de musicología, 15 (1992), pp. 389-401.

34 Williams, Illustrated Beatus, III, pp. 24-25; J. Williams, "El Beato de San Millán y el arte de los Beatos", in El Beato de San Millán Códice 33, Volumen complementario a la edición facsimil, Madrid, 2005, pp. 85-134

35 For RAH 18 see M. DíAz y DíAz, Libros y librerías en la Rioja altomedieval, Logroño, 1979, pp. 201202, as after 1095 and heavily influenced by the Gallican model. 


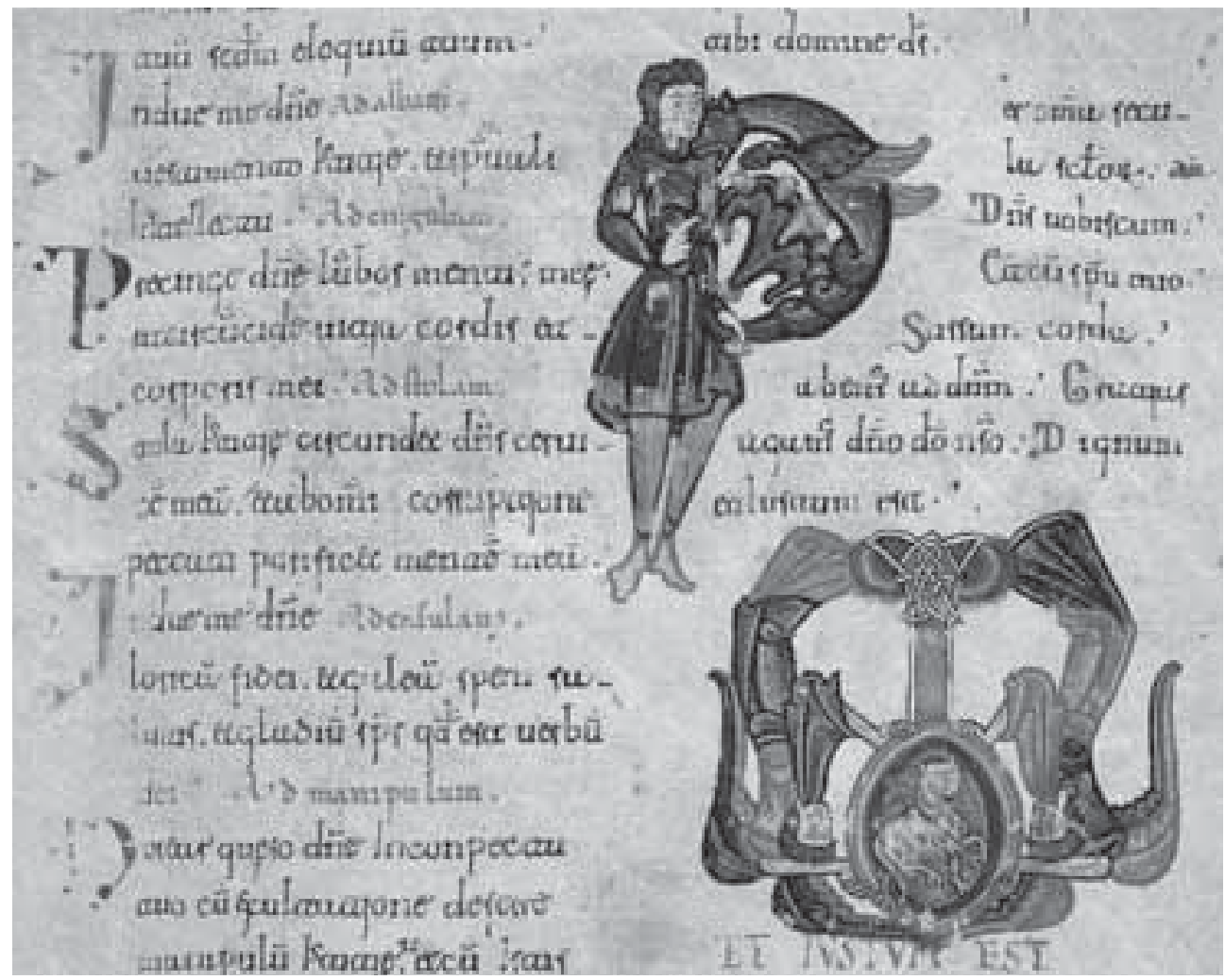

Fig. 8. Initials, Madrid, Real Academia de la Historia, Cod. 18, fol. 13r.

parallels with books from San Millán, and Moralejo stressed parallels with the initials of San Millán (fig. 9) ${ }^{36}$ Fernando, who after Atapuerca could consider Navarra as within his kingdom, was no stranger to San Millán: on two occasions in 1055 he witnessed donations to San Millán. ${ }^{37}$ Moreover, a charter recording a donation to San Millán by Fernando's brother, García, in 1052 ends Fructuosus exaravit. ${ }^{38}$ This was not witnessed by the abbot of San Millán, but solely by the bishops of the realm, and Fructuosus may well have been a royal scribe.

There is in fact a Psalter attributed to San Millán in the middle of the eleventh century that offers suggestive if not identical parallels with the figure style of the Diurnal..$^{39}$ After classifying the writing of this Psalter as that of San Millán, Díaz y Díaz concluded

36 "Notas", p. 60 [=PAG, II, p. 31]

37 A. Ubieto Arteta, Cartulario de San Millán de la Cogolla (759-1076), Valencia, 1976, pp. 281-282.

38 Ibid., p. 276.

39 Archivo Histórico Nacional Cod. 1006. See "Psalterio y Libro de Cánticos", in Sancho el Mayor y sus herederos, I, pp. 128-129; S. Silva y VerÁstegui, La miniatura en el monasterio de San Millán de la Cogolla, Logroño, 1999, pp. 25-33. 

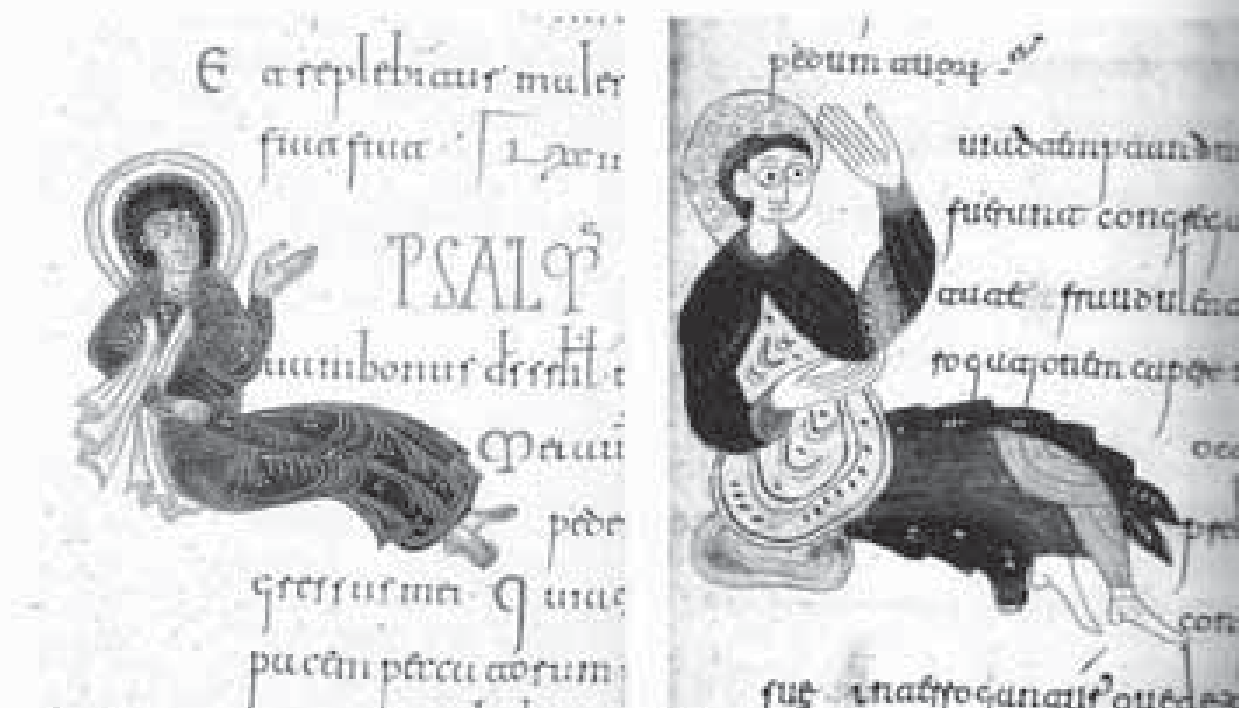

Fig. 9. Initials, Santiago de Compostela, Biblioteca Universitaria, Ms. 609 (Res. 1), fol. 66v/Madrid, Real Academia de la Historia, Cod. 39, fol. 134r (Art of Medieval Spain a.d. 500-1200, New York, 1993, p. 132).

que todas las aparencias [of the content] apuntan a un máximo de concordancias para el Salterio con codices originarios de la región leonesa, citing the Diurnal. In a note, however, he questioned the assumption that the Diurnal was Leonese in origin and called for a consideration of the ambiente castellano-riojano. ${ }^{40}$ This Psalter has an illustration of David (fig. 10) whose style, while not as advanced that of the Diurnal, has totally abandoned Mozarabic conventions. One also sees stylistic traits of the Diurnal in an illustration of Christ enthroned above a file of figures illustrating a canticle in a manuscript in Paris (BN Smith-Lesouëf 2) that may have been copied at San Millán. ${ }^{41}$

Drawing heavily on Einhard's life of Charlemagne, a grand patron of arts in service of the faith, the author of the Silense makes a special case for Fernando's devotion:

He observed the Christian religion, to which he had been devoted since his childhood, with the greatest piety. He embellished this church which he had newly built and consecrated in honor of the holy bishop Isidore with gold and silver of the utmost beauty and precious stones and silken hangings. He would tirelessly attend church morning and evening, also for the late-night hours and at the time of the sacrifice, and he rejoiced exceedingly to join with the voices of the clergy in praise of God. ${ }^{42}$

40 Díaz y Díaz, Libros y librerías, p. 179.

41 F. Avrit, Manuscrits enluminés de la péninsule ibérique, Paris, 1983, p. 27, pl. A; A BoYLAN, Manuscript Illumination at Santo Domingo de Silos (Xth to XIIth Centuries (Diss., University of Pittsburgh, 1990), pp. 301-305.

42 R. Fletcher and S. Barton, The World of El Cid: Chronicles of the Spanish Reconquest, Manchester and New York, 2000, p. 61. 


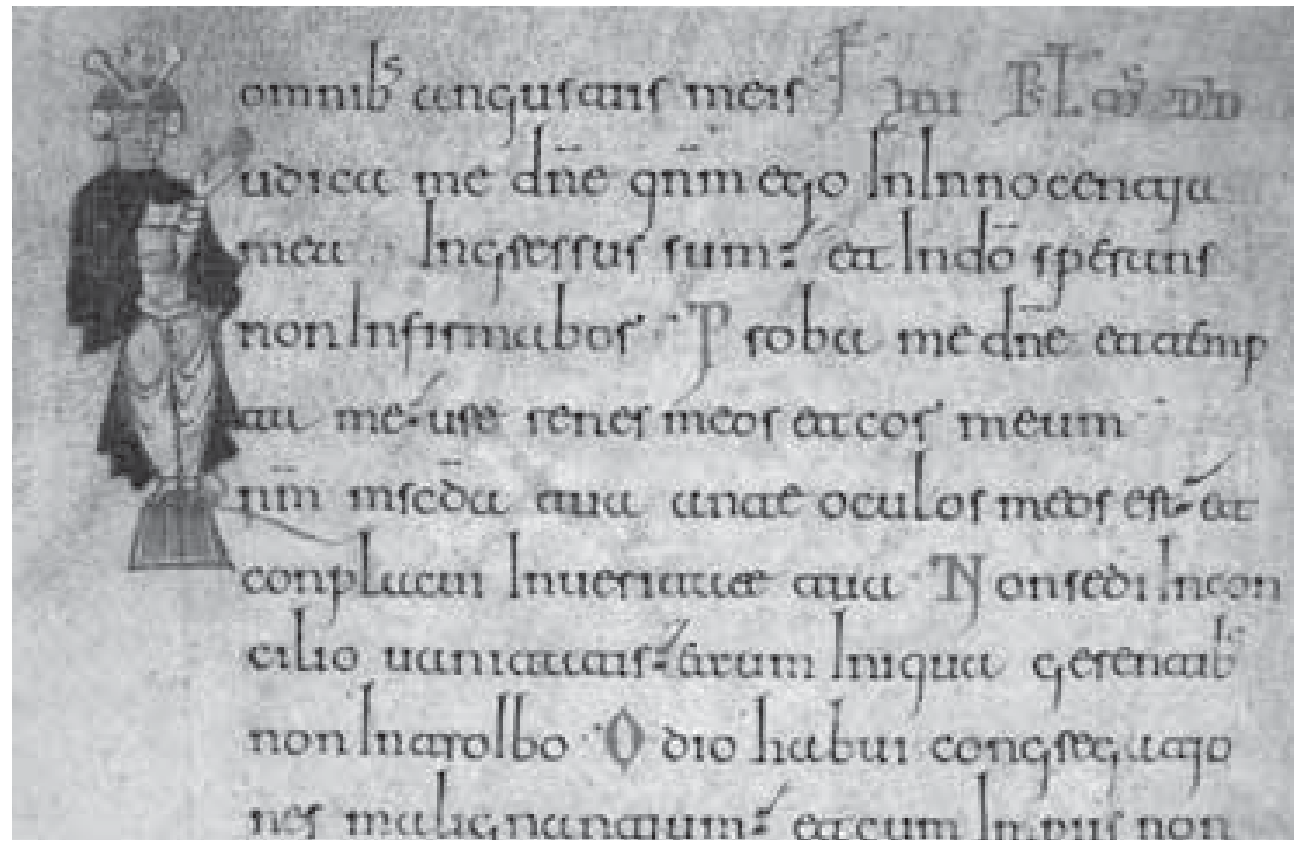

Fig. 10. David, Madrid, Archivo Histórico Nacional, Cod. 1006, fol. 17v.

Fernando would have modeled himself on David and Solomon. With the Diurnal and the splendid treasury amassed by him and Sancha as evidence, it was not a vainglorious ideal.

If the Diurnal suggests influences from the south of France, the treasury assembled by Fernando and Sancha testifies to other orientations. One points toward the Holy Roman Empire, a zone that dominated the world of exquisite liturgical objects of metal and ivory. The surest sign of Germanic contacts is provided by the Casket designed to receive the relics of Isidore of Seville in León in 1063. Gómez-Moreno and others after him have linked style and iconography to the reliefs of Bishop Bernward's great bronze doors at Hildesheim of 1015, themselves dependent on the biblical iconography made familiar by the scriptorium of Saint-Martin de Tours. ${ }^{43}$ The complicated vine-scroll patterns on the pilasters dividing the scenes and the angular interlace panels of the lid (figs. 4 and 5) also have counterparts in Rhenish art of the middle of the century. ${ }^{44}$

43 M. Gómez Moreno, "El Arca de las reliquias", p. 212; J. Williams, "Tours and the Early Medieval Art of Spain", in Florilegium in Honorem Carl Nordenfalk Octogenarii Contextum, Stockholm, 1987, pp. 197208; I. BANGO, "Relicario de San Isidoro", in Maravillas de la España medieval. Tesoro sagrado y monarquía, dir. I. BAngo, Valladolid, 2001, I, pp. 228-229. D. Perrier ("Die spanische Kleinkunst des. 11. Jahrhunderts", Aachener Kunstblätter, 52 (1984), pp. 29-150, at 87-91) discounted an Ottonian source and proposed an Aquitanian origin on the basis of the treasury items of Sainte-Foi de Conques.

44 See the borders of the wooden doors of Sankt Maria im Kapitol, Cologne, in R. Wesenberg, Frühe mittelalterliche Bildwerke: Die Schulen rheinischer Skulptur und ihre Ausstrahlung, Düsseldorf, 1972, figs. 41-48 for interlace with angles and figs. 39-40 for rinceaux organized into lozenge shapes. 
Although the Arca of San Isidoro is not recognizable in the inventory of church furniture donated in 1063 by Fernando and Sancha to San Isidoro, ${ }^{45}$ the palatine church of their capital, others equally sumptuous are listed:

A frontal of pure gold with emeralds and sapphires; all manner of precious stones and crystals; three silver frontals, one for each altar; three crowns of gold, one of them with six alphas around it; another crown is of gold with amethysts and enamels, the third crown is actually the diadem on my head; a small box of crystal covered with gold; a cross of gold studded with precious stones and enamels; another cross of ivory with the effigy of the crucified Lord; two censers of gold with the incense boxes also of gold; another censer of silver, very large; a chalice and paten, both of gold with enamels.

In all some fifty items are listed. It was an extraordinary moment. The largesse of predecessors in Oviedo offered Fernando a model, but this magnificent endowment of a palatine church with a treasury would also reflect Fernando's intention to put an imperial stamp on his capital, in imitation of the Carolingians and Ottonians. The focus on the treasury had begun earlier, with the copy of the Beatus in 1047 and the Casket of 1059 for Pelayo, patron saint of the royal churches before the arrival of Isidore's body ${ }^{46}$.

The range of tastes and techniques exhibited by Fernando's and Sancha's collection is extraordinary. Although the styles of ivories in the treasury have no perfect match with ivories elsewhere, there are iconographic clues that point to northern models. That is the case with the ivory plaque in the Louvre (fig. 11) ${ }^{47}$ and the ivory Cross with Fernando and Sancha commemorated by inscription at its foot. ${ }^{48}$

Not only were Gallic and Ottonian traditions drawn on, but peninsular ones as well, Andalusian included. As if searching for a justification for its presence, an Islamic heart-shaped silver box was converted to a reliquary for San Pelayo as an added inscription testifies. ${ }^{49}$ Another Islamic gilt silver box worked with niello, from Egypt, was probably in the treasury of San Isidoro in Fernando's time.$^{50}$ On the other hand, a box with fifty-seven small sardonyx plaques held by a framework of gilded and nielloed silver has no Islamic parallel and must represent local arti-

45 P. Blanco Lozano, Colección diplomática de Fernando I (1037-1065), León, 1987, 166-72; A. Franco MAtA, "El tesoro de San Isidoro y la monarquía leonesa," Boletín del Museo Arqueológico Nacional, IX (1991), 35-68. On the treasury and Sancha's major role see MARTIN, Queen as King, pp. 51ff.

46 Blanco Lozano, Colección, pp. 236-239.

47 Art of Early Medieval Spain, pp. 246-247. The size (26.4 x $13.9 \mathrm{cms}$.) would have well suited it to be on the cover of the Bible of 960 in the library of San Isidoro if one imagines it with a jeweled border. That border would have made it a likely prize for the Napoleonic troops that occupied San Isidoro in 1808, and would explain the plaque's arrival in Paris.

48 Ibid., pp. 244-246.

49 Ibid., pp. 98-99.

50 Ibid., pp. 99-100. 


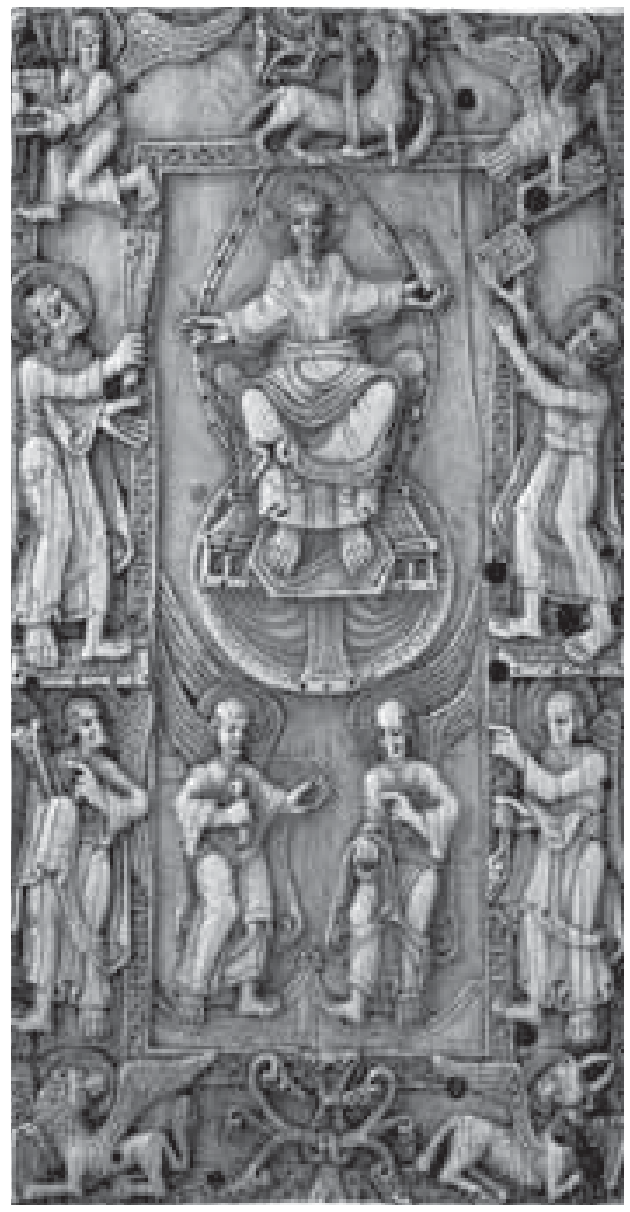

Fig. 11. Ivory plaque, Paris, Musée du Louvre. sanship of an imaginative order. ${ }^{51}$ The famous Agate casket of Oviedo could have been an inspiration. ${ }^{52}$

The church enriched by this treasury had just replaced an earlier one dedicated to the Baptist. As we know from the surviving foundations and portions of the northern and western walls incorporated in the actual Romanesque church, it conformed in style to Asturian formulas, as found at San Pedro de Teverga several decades later, ${ }^{53}$ with an especial resemblance and dimensions that match precisely those of the church dedicated in 893 at Valdediós by a predecessor on the Leonese throne, Alfonso III..$^{54}$ In contrast to the Book of Hours, it seems to reflect a conservative taste. It was suitable in terms of size if one remembers it was to serve as a palace, that is, familial, chapel, and not serve a large monastic community or pilgrims on the way to Santiago..$^{55}$ Although it is difficult to imagine what other kind of model Fernando's architects would have turned to, this choice may also have been designed to reinforce Fernando's imperial claims, for it proclaimed through its shape Fernando's

${ }^{51} \quad$ Ibid., pp. 255-256.

52 Ibid., pp. 143-145.

53 J.L. SENRA, "Architecture et décor dans le contexte de la colonization clunisienne des royaumes septentrionaux de la péninsule ibérique", in Hauts lieux romans dans le sud de l'Europe (XIe-XIIe siècles), Cahors, 2008, pp. 11-71, at pp. 25-27; C. García de Castro Valdés, La colegiata de San Pedro de Teberga, Llanera, 2006.

54 It has been suggested (G. Bото VArela, "Morfogénesis espacial de las primeras arquitecturas de San Isidoro. Vestigios de la memoria dinástica leonesa", in Siete maravillas del románico español, Aguilar de Campoo, 2009, pp. 153-91) that the foundations belonged to the church erected by Alfonso V, and that the church of Fernando would have extended further to the east with a more ample choir. However, when the floor of the actual church was removed in 1971, revealing just below the surface the foundations of Asturian shape, there was no sign of foundations for such an extension of the east end. See also note 81, WiLLIAMS, "San Isidoro exposed".

55 However, a function as a pilgrimage church for Fernando's palace chapel has been proposed by F. SeEHAusen, "Wege zum Heil - Betrachterlenkung durch Architektur, Skulptur und Ausmalung im Panteón de los Reyes in León,’ Kunsttexte.de, 4/2009 - 1, pp. 1-37. 
place, as ruler, in an Asturian, that is, Leonese, genealogy which carried with it imperial rank. ${ }^{56}$

The death of Fernando so movingly portrayed in the Silense meant a repeat of history in that the kingdom was divided among brothers and only after war and fratricide could it be united and pursue positive reorganization and expansion. It was, nevertheless, a new era. Perhaps nothing symbolizes better the extent and nature of the change than the matrimonial history of the new royal family: Alfonso never took a Spanish wife, that role being assigned to four French women and one Italian; his daughters were married to Frenchmen. It is true that Fernando in his final years had campaigned rather continuously, but León, his capital and site of his palace, were clearly home. His son Alfonso would be even more constantly on the move, but he too would have a home, in Sahagún next to the monastery of Saints Facundus and Primitivus. As the author of the Primera Crónica Anónima stated: Amó mucho este monasterio así como proprio palaçio suyo. ${ }^{57}$

Thanks to the tradition of female patronage, institutionalized in the infantazgo, wives, sisters and daughters would keep San Isidoro at the forefront of artistic interest..$^{58}$ The author of the Silense went out of their way to acknowledge the role of the daughter of Fernando and Sancha as donor: "All of her life she [Urraca] followed her desire to adorn sacred altars and the vestments of the clergy with gold, silver and precious stones." ${ }^{\circ 9}$ Unfortunately, we have lost a spectacular example of this largesse, a Cross two meters tall with an ivory corpus on a cross of gold and silver studded with gems. It included an effigy of Urraca at the foot, in gold repousée, identified by inscription. ${ }^{60} \mathrm{We}$

56 J. Williams, “San Isidoro in León: Evidence for a New History,” Art Bulletin, 55 (1973), pp. 171-184; T. Martin, Queen as King, p. 49.

57 A. Ubieto Arteta (ed.), Crónicas anónimas de Sahagún, Zaragoza, 1987, p. 16.

58 See especially R. WALKER, "Sancha, Urraca and Elvira: the Virtues and Vices of Spanish Royal Women 'Dedicated to God"', Reading Medieval Studies, 24 (1998), pp. 113-138; A. VINAYO, "Reinas e infantas de León, abadesas y monjas del monasterio de San Pelayo y San Isidoro," in Semana de historia del monacato Cántabro-Astur-Leonés, Oviedo, 1982, pp. 123-35; T. MARTIN, «Hacia una clarificación del infantazgo en tiempos de la reina Urraca y su hija la infanta Sancha (ca. 1107-1159),»e-Spania, Revue électronique d'études hispaniques médiévales 5, June 2008.

59 Fletcher and Barton, World of El Cid, p. 33.

60 See J. Manzano, Vida y portentosos Milagros de el glorioso San Isidoro, arzobispo de Sevilla, Salamanca, 1732, p. 383; M. Risco, Historia de la ciudad y corte de León y de sus reyes, León, 1792, II, pp. 146-7 and España. Sagrada, XXXV, p. 357. According to Manzano the stem was 2 1/2 varas tall and the cross bar 1 1/2. A. Porter (Romanesque Sculpture of the Pilgrimage Roads, Boston, 1923, I, pp. 40-41) proposed that the ivory corpus purportedly from the Cistercian convent founded in the mid-twelfth century at Carrizo de la Ribera (Astorga) and now in the Museo Arqueological Provincial in León (Art of Medieval Spain, pp. 248-250) was from this cross. Its relatively small size of $33 \mathrm{cms}$. in height would seem to rule this out if Manzano's description is to be trusted, as does the bejewelled golden skirt described by Manzano. Urraca also gave a large gold and gemmed cross with an ivory corpus to the Cathedral of León at the foundation of a new building by Bishop Pelayo in 1073. It is lost but see M. Risco, España sagrada, XXXVI, Madrid, 1787, app. 28, p. LIX. 
gain some idea of the sumptuousness of conception, however, from the surviving chalice displaying her name (fig. 12). ${ }^{61}$ It cleverly incorporates two Antique onyx cups so that one can function as the bowl and the other, inverted, as the foot. These are encased in gold filigranes uniting gems and pearls and small plaques of enamel. A singular glass head attached to the rim, while not Antique, suggests a taste shared with the Ottonian patrons for Antique cameos in the decoration of church furnishings. ${ }^{62}$ The Germanic background of the techniques employed are as apparent as they were in the case of the Isidore casket.

In addition to the largesse of Urraca on behalf of León, she restored the monastery of Eslonza in 1099 and gave it a gold and silver textile altar hanging, a silver reliquary and a dozen books, including a Beatus Commentary that cannot be traced. ${ }^{63}$ At the same time the Panteón de los

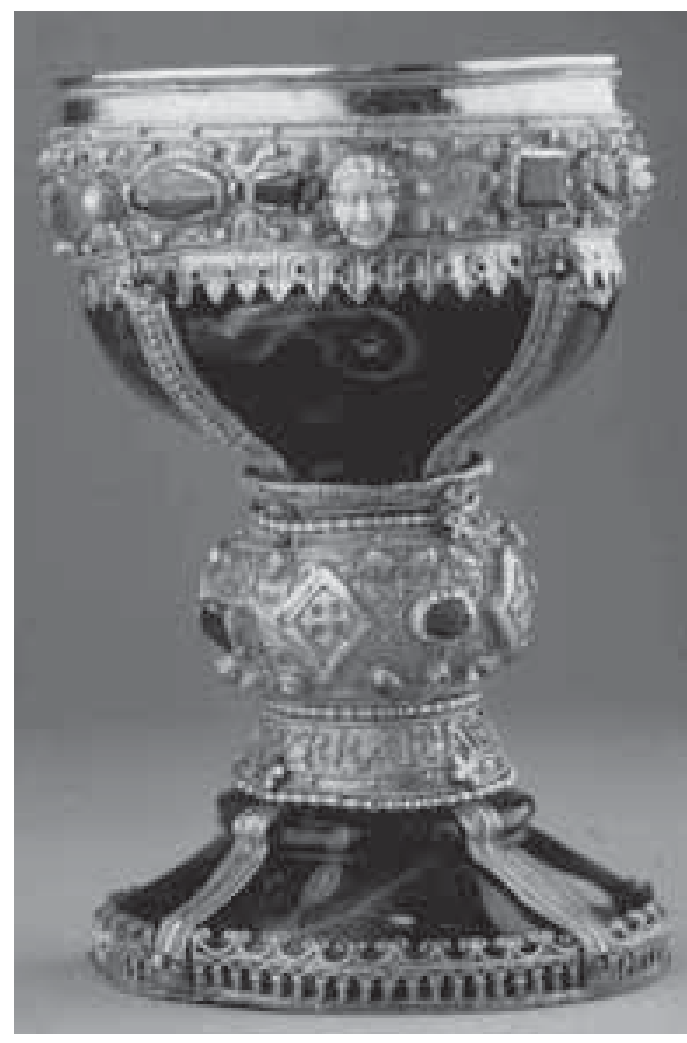

Fig. 12. Chalice of Urraca, León, Colegiata de San Isidoro. Reyes rose while she presided at San Isidoro, challenging Santiago for primacy as the kingdom's first truly Romanesque structure. ${ }^{64}$ The new basilica would also have been undertaken before she died in 1101 , and would have reached near completion before it was redesigned to incorporate a transept. ${ }^{65}$

${ }^{61}$ Art of Medieval Spain, pp. 254-255; Maravillas de la España medieval, p. 335.

${ }_{62}$ F. PRADO-VILAR has proposed that it is a portrait of Urraca ("Lacrimae rerum", p. 13).

${ }_{63}$ A. de YePES, Historia general de la orden de San Benito, IV, Irache, 1621, app. 36.

${ }^{64}$ Williams, "San Isidoro". For claims that there is no reason to conclude that the actual Panteón is posterior to Fernando's tenure see M. PozA YAGÜE, "Entre la tradición y la reforma. A vueltas de nuevo con las portadas de San Isidoro de León," Anuario del Departamento de Historia y Teoría del arte, XV (2003), pp. 9-28, at p. 16. For the Fernandine origin of the actual Pantheon see also H. BredeKamp and F. SEehausen, "Das Reliquiar als Staatsform. Das Reliquiar Isidors von Sevilla und der Beginn der Hofkunst in León," in Reliquiare im Mittelalter, ed. B. Reudenbach, G. Toussaint, Berlin, 2005, pp. 137-164; Seehausen, "Wege zum heil", p. 32, n. 5; ID., "Baugeschichte als dynastisches Konstrukt: Die Bauphasen und ihre Interrelation mit der Kapitellskulptur von San Isidoro in León”, in Hispaniens norden im 11. Jahrhundert. Christliche Kunst im Umbruch, ed. A. Arbeiter, C. Kothe, B. Marten, Petersberg, 2009, pp. 200-211.

${ }_{65}$ T. MARTin, Queen as King, p. 126. 
We lack evidence of Alfonso's direct interest in the treasury at San Isidoro; it would have been redundant given Urraca's character and resources, but it cannot be ruled out. His patronage enriched treasuries elsewhere. Sahagún received a magnificent silver altar frontal with figures in relief ${ }^{66}$ Although it is lost, Ambrosio de Morales recorded that it was almost five meters wide. A comparable object survives: the Arca Santa of the cathedral of Oviedo ${ }^{67}$ Although its size is more compatible with that of an altar than a reliquary, its size seems designed to confirm the large number of relics, supposedly brought from Jerusalem to Toledo in the Visigothic era. Their transfer to the new shrine supposedly took place in 1075, but the document that supplies this date seems to be a forgery ${ }^{68}$ This reliquary must have been commissioned by Alfonso VI, probably around 1100 . Three sides are covered with scenes of Christ in Majesty, the Apostles and the life of Christ from the Annunciation to the Ascension in silver repousée, and on its upper surface is a niello crucified Christ. Because the style had no counterpart in the peninsula and by comparison of St. Andrew in the Ascension with an apostle in an Anglo-Saxon Homilary, Serafín Moralejo proposed that a goldsmith from England was responsible. ${ }^{69}$

Exceptionally, Anna, the Virgin's mother, is present at the Annunciation and in the Flight into Egypt on the Arca Santa. This iconographic peculiarity provides a concrete link to León for she appears twice in the contemporary murals of the same scenes in the frescoes of the Panteón de los Reyes, Urraca's addition to the church of San Isidoro.

Rose Walker has stressed the emphatic familial dimension of the iconography of the Panteón. ${ }^{70}$ This is brought home not only by an inscription above the doorway leading from the Panteón to Fernando's church, but also by the inclusion nearby of a scene based on the Beatus of Fernando and Sancha, as the identical inscriptions -UBI PRIMITUS IOHANES CUM ANGELO LOCUTUS EST-attest. Indeed, the choice of subject, the commissioning of Revelation, would have been inspired by the desire to honor the commissioners of the Commentary of $1047 .^{71}$ It is significant, then, that this subject appears immediately above the portrait of Fernando and Sancha in the Crucifixion. Just to the right in the spotlighted area of the tympanum

66 A. de Morales, Viage por orden de D. Phelipe II. a los reynos de León, y Galicia, y Principado de Asturias, ed. H. Risco, Madrid, 1765, p. 36. Also lost are «a cross of gold, of marvelous size, surrounded and covered with precious stones» that Alfonso gave to the church of Nogal when Queen Constanza died (1093), and "a cross of gold covererd with many precious stones" given to to San Salvador de Villaverde de Valdevidriales on the death of Queen Berta (1108?). See Ubieto ARTeta, Crónicas anónimas, p. 17.

67 "Arca Santa of Oviedo", in Art of Early Medieval Spain, pp. 259-260. See the study by Rose Walker in this volume.

68 B. ReILly, The Kingdom of León-Castilla under King Alfonso VI 1065-1109, Princeton, 1988, p. 85.

69 S. Moralejo, "Les Arts sumptuaires hispaniques aux environs de 1100", Les Cahiers de Saint-Michel de Cuxa, 13 (1982), pp. 285-310, at 288-289 [=PAG I, pp. 224-225].

70 R. Walker, "The Wall Paintings of the Panteón de los Reyes at León: A Cycle of Intercession", Art Bulletin, LXXXII (2000), pp. 200-225.

71 J. Williams, Illustrated Beatus, I, pp. 99-100; R. WaLker, “Wall Paintings”, pp. 217-218. 
above the doorway communicating with the church an engraved plaque carried by angels acknowledged that the church was the work of Fernando and Sancha. As Walker concluded, "it is difficult to conceive of a more emphatic way of drawing attention to Fernando and Sancha's patronage as a means of attaining salvation."'72

To return to the unusual presence of Saint Anna, the mother of Mary: was she added out of a desire to underscore the feminine, matriarchal dimension of the family? The common presence of her in works separated geographically and in technique suggest royal patronage went beyond mere commission and endowment to iconographic programming that, one assumes, would not be exclusively in lay hands. Indeed, the rich assortment of subjects on the walls and vaults and capitals of the Panteón, possibly with "liturgical debts" to both the Mozarabic and the newly introduced Roman liturgy, ${ }^{73}$ and with a fixed eye on the main goal of commemoration of, and intercession for, the founders, presumes the agency of clerical counselors.

Some subjects might have evolved from local sources, but many are exotic. The Arca Santa and the frescoes were more or less contemporaneous. In style the two are not identical, but drew on different sources. As we saw, the Arca Santa seems linked to England. On the other hand the murals of the Panteón have their closest analogy stylistically with the frescoes in the crypt of Notre-Dame-la-Grande in Poitiers. ${ }^{74}$ A French iconographic orientation is evident also. For the first time recorded anywhere Martial of Limoges is present at the Last Supper, a detail based on a legend popularized by the monastery at Limoges. ${ }^{75}$ Also unprecedented is another Gallic saint, Eligius. ${ }^{76}$ The cult of this famous artisan popularly associated with the Merovingian king Dagobert's patronage was centered in Noyon, where he was buried, but it was only at the end of the twelfth century that it began to flourish, and only in the thirteenth century did Eligius begin to appear in art with any regularity. ${ }^{77}$ Do the multiple Frankish liaisons on Alfonso's part - including four French wives - explain such a program? Or was it the result of the wave of recruitment of clerics beyond the Pyrenees?

Saint George had a Spanish as well as a French cult, but his depiction establishes an Hispanic context, for he is combating a Moor. ${ }^{78}$ George was the patron saint of Aragón and legend had him miraculously intervening there in the battle of Alcoraz

72 Ibid., p. 211.

73 Ibid., p. 220.

74 O. Demus, Romanesque Mural Painting, New York, 1970, p.420, pl. 124, as end of 11th century; P. Deschamps, M. Thibout, La peinture murale en France: le haut moyen age et l'époque romane, Paris, 1951, pp. 64-67, pl. XXI, as mid-11th century.

75 J. Williams, "Marcialis Pincerna and the Provincial in Spanish Medieval Art", in Hortus Imaginum: Essays in Western Art for Harold E. Wethey, ed. R. Engass and M. Stokstad, Lawrence (Kan.), 1974, pp. 29-36; R. WALker, "Wall Paintings", pp. 215-216.

76 A. Viñayo González, Pintura románica: Panteón Real de San Isidoro de León, León, 1971, fig. 46.

77 R. BranNER, «Le Rouleau de Saint Eloi», L'information d'histoire de l'art, 12 (1967), pp. 55-73.

78 A. Viñayo GonzÁlez, Pintura románica, fig. 45. 
in 1096. ${ }^{79}$ After her father's death in 1109 Queen Urraca was briefly united with Alfonso I of Aragón. It was around this time that the very original Reconquest tympanum was installed over the southern, public, doorway of the palatine church with the aid of carvers from Aragón. George's presence may justify a date of around 1100 for the frescoes.

When Alfonso VI consolidated his power on the Leonese throne in 1072, there was scarcely any architecture in his realm that warranted the label "Romanesque." (Or outside of it, Cataluña, as always, being an exception.) At his death in 1109 there was no recent architecture that was not decidedly Romanesque, and indeed a mature Romanesque that incorporated in a major way sculpture on figured capitals and reliefs. Coincidently, this very same period witnessed an extraordinary surge in the popularity of the pilgrimage to Santiago along what had originally been a major Roman road. It must be said, too, that most of the major examples of the new art were on, or very near, this artery.

We have until now been discussing patronage of a more or less direct sort, in that there is a good chance the ruler commissioned the work. With Alfonso so often in the saddle, and when not, in residence in Sahagún, it is logical to assign to the Infanta Urraca's patronage the beginnings of Romanesque architecture in León, with her addition of the palace partially occupying the Roman walls and extending eastward in the form of a room and a large tribune that communicated by a door and balcony with the palatine church (fig. 13). ${ }^{80}$ Tribunes were traditional in royally connected northern peninsular churches, with examples at Oviedo (Santullano) and at Valdediós. This one, however, was exceptional in being part of the palace. As support this large room required the vaulted rez-de-chausée. As a result, a convenient space for a royal cemetery was offered, and indeed was splendidly decorated beyond the requirements of a mere basement story. The Panteón of San Isidoro has usually been seen as a natural outcome of a Spanish tradition of royal burial, with the tribune, in reality a room of the palace once divided by a wall at midpoint, a secondary result. ${ }^{81} \mathrm{In}$ fact, the tribune dictated the presence of the Panteón.

The Panteón was splendidly conceived with historiated capitals and murals. Be-

\footnotetext{
79 The Chronicle of San Juan de la Peña, tr. L. Nelson, Philadelphia, 1991, pp. 22-23.

80 T. MARTIN, "Chronicling the Iberian Palace: Written Sources and the Meanings of Medieval Christian Rulers' Residences”, Journal of Medieval Iberian Studies, 2: 1 (2010) pp. 109 -139, at 126ff.

${ }^{81}$ The Panteón has been consistently linked to a Spanish tradition of royal cemeteries at the western end of churches. At times the tribune has been recognized as an afterthought erected later although there is nothing in the fabric that suggests discontinuity. See I. BANGO, "El espacio para enterramientos privilegiados en la arquitectura medieval española," Anuario del Departamento de Historia y Teoría del Arte, 4 (1992), pp. 93-132 at 104-105; E. FERNÁNDEZ, "Reflexiones sobre la evolución hacía el románico de las fórmulas artísticas altomedievales", in Hispaniens norden im 11. Jahrhundert. Christliche Kunst im Umbruch, ed. A. Arbeiter, C. Kothe, B. Marten, Petersberg, 2009, pp. 48-72, at 51. However, for the proposition that a role as a Panteón was not crucial originally to its design and function see Williams, "San Isidoro Exposed: The Vicissitudes of Research in Romanesque Art”, Journal of Medieval Iberian Studies, 3-1, 2011, pp. 93-116.
} 


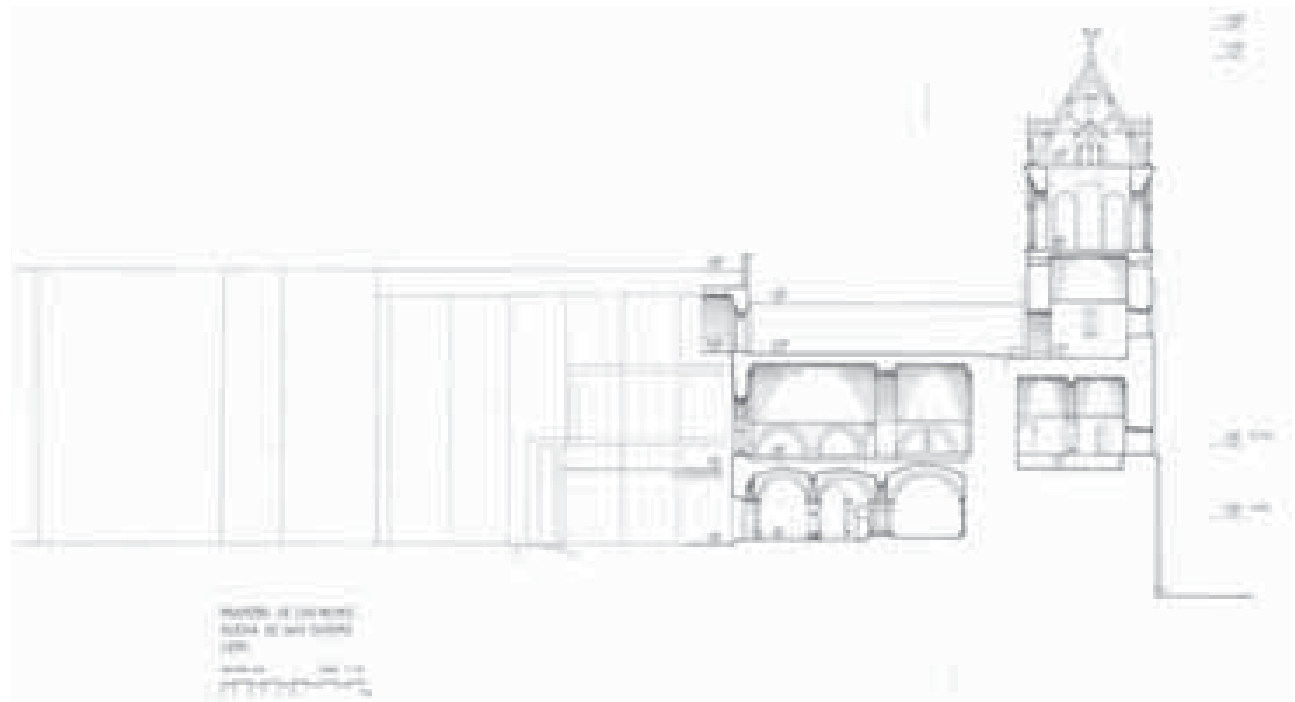

Fig. 13. Longitudinal Section of Panteón and Tribune of San Isidoro de León (J. Williams).

cause of the failure of its capitals to reflect the prodigious addition to the repertory of Romanesque sculpture generated at Jaca and Frómista it would seem to be dated not earlier than $1080 .{ }^{82}$ It is possible of course that Alfonso had a role in this addition. Like the architecture and sculpture that would succeed it in León and further east in Aragón, it breaks with native traditions by borrowing forms and techniques originating north of the Pyrenees. As a confirmation of the date towards the end of the eleventh century, some of the capitals indicate the new style was imported from Toulouse. The Punishment of Greed in the tribune used by the royal family to observe services in the church employs a formula invented for the Porte des Comtes, the transept doorway of Saint-Sernin de Toulouse. The ball and pinecone capitals of the Panteón have to be linked to comparable capitals from the east end of the same church, and therefore from around $1080 .{ }^{83}$ As the new basilica progressed the arrival of sculptors from Aragón can be deduced from the style of the Puerta del Cordero.

The relatively primitive character of some of the sculpture of the Panteón indicates that assistants rather than masters brought the ideas from Toulouse to León. Therese Martin has proposed that the masons assembled in León had first arrived in the area

82 J. Williams, "León: The Iconography of a Capital", in Cultures of Power: Lordship, Status, and Process in Twelfth-Century Europe, ed. T. BIsson, Philadelphia, 1995, p. 251.

83 T. Martin, Queen as King, p. 79; M V. Herráez, M. Valdés, M.C. Cosmen, "La escultura de San Isidoro de León y su relación con otros talleres del Camino de Santiago", a lecture at the colloquium Santiago de Compostela: Pilgerarchitectur und bildliche Representation in neuer Perspektive, Bern, 25-27. 3. 2010, to be published. 
with the decision by Queen Constanza (1079-1093) to erect a residence at Sahagún. ${ }^{84}$ Constanza was Burgundian. Why had Toulouse been the supplier of these masons? Alfonso's daughter Elvira would be married to Raymond of Toulouse by 1094, but the conduit for earlier contact with Toulouse remains unknown. Saint-Sernin was of course a major church under construction in the modern style precisely when Urraca undertook a new palace and basilica. Pedro of Rodez, the bishop of Pamplona from 1083 to 1115 might be a candidate for the contact that brought knowledge of Toulouse to the court at León. ${ }^{85} \mathrm{He}$ was born in Rodez, near Albi and would die in Toulouse. His links to his former abbey of Sainte Foi de Conques and Toulouse were close and continuous and included gifts of Aragonese churches to the two. His appointment to his see was by Sancho I Ramírez of Aragón, an ally of Alfonso VI since the Rioja had been divided between them in 1076 and established a common frontier. ${ }^{86}$ The eventual extent of Pedro's ties to the kingdom of León are clear from his engaging Maestro Esteban for his own cathedral and Gelmírez's invitation to Pedro of Rodez to consecrate the chapel of Sainte Foi in the cathedral of Santiago in 1105.

More than anything it is the failure of the sculpture of the Panteón to exhibit the styles we associate with the heyday of the Camino that suggests that it was the first Leonese structure involving vaults carried on compound piers with historiated capitals, and to be dated therefore around 1080. In attributing this to Urraca we are assuming, without direct evidence, that Alfonso VI was too disinterested or busy to have had some role as patron. His capital effectively was Sahagún and there is ample written testimony of its importance. ${ }^{87}$ Indeed, Alfonso early on designated it as his final resting place, and designed a new Panteón, a rival to the one erected by his sister in León, for himself, his wives and other dignitaries including, perhaps, Alfonso, the son of his ayo, Pedro Ansúrez, whose sarcophagus lid is today in Madrid. ${ }^{88}$ Stylistically it owes nothing to Cluny, but as Debra Hassig demonstrated, its exceptional depiction of the defunct as a full-figured clothed individual may be linked to particular liturgy for the dead practiced at Cluny. ${ }^{89} \mathrm{Of}$ this complex of church, palace, baths, dwellings for foreign settlers, market and fuero, precious little survives today. ${ }^{90}$ But it was the epicenter of change, including the substitution by

84 Ibid., pp. 73-74.

85 J. Goñ Gaztambide, "Los obispos de Pamplona del siglo XII,” in Anthologica Annua 13 (1965), pp. 147-195; J. Williams, “¿Arquitectura del camino de Santiago?”, Quintana, 7 (2008), pp. 155-177, at p. 161.

86 ReILly, Kingdom of León-Castilla, pp. $161 \mathrm{ff}$.

87 J.L. SENRA, Hauts lieux, pp. 44-48.

88 S. Moralejo, "La lauda sepulcral de Alfonso Ansúrez (†1093): su lugar en el desarrollo de la escultura románica hispánica y sus relaciones con el arte jaqués", Primer Coloquio de arte aragonés, Teruel, 1978, pp. 197-218 [=PAG I, pp. 131-139].

89 D. Hassig, "He Will Make Alive Your Mortal Bodies: Cluniac Spirituality and the Tomb of Alfonso Ansúrez”, Gesta XXX/2 (1991), pp. 140-53;

90 We have also lost the cathedral in Burgos that rose during Alfonso's reign. See W. WhitehiLl, Spanish Romanesque Architecture of the Eleventh Century, Oxford, 1941 (1968), pp. 210-211. 
the Roman rite for the ancient Hispanic rite. Although Sahagún was not subjected to the Burgundian abbey, the Cluniac rule was adopted. Bernard de Sauvetat, a former monk of Cluny, was a forceful agent of the Europeanizing cultural climate Alfonso inherited from his father. Bernard had been in Cluny's scriptorium, and the Beatus of Burgo de Osma, completed as he left Sahagún for his installation as archbishop of Toledo, was the first peninsular copy in a Romanesque style. Rich in innovation, it testifies to the high intellectual level of the monastery of Sahagún. ${ }^{91}$ There is no evidence to link its style to the direct intervention of Bernard. Rather it reflects the continued embrace of the Europeanizing culture Alfonso inherited from his father.

If Sahagún's true role in the history of Romanesque is beyond recovery, Alfonso's crucial link to the greatest of the churches on the Camino, the cathedral of Santiago de Compostela, is well documented. Alfonso had to be aware of the special place the apostolic shrine had in his father's life. It is recorded in exceptional detail in the account of Fernando's life that is the focus of the Historia Silense. ${ }^{92}$ Alfonso's role in the elevation of the grand new basilica was crucial. He arrived in Santiago in January 1075 with his full court. A grand council had convened. It was a fitting audience for his gift to the apostolic church of 30,000 dinars from the booty collected in Andalucía the previous year. ${ }^{93}$ Additional royal support would come later, in 1107, when Santiago was given the right to coin money specifically to help build the church. ${ }^{94}$

The capital at the entrance to the chapel of San Salvador which commemorates Alfonso's part in promoting the cathedral has a counterpart in capitals of the Auvergne and Conques. ${ }^{95}$ One on the exterior of the San Salvador chapel is based on the same Toulousan formula for the punishment of vice that we saw in the tribune of the palace of San Isidoro. ${ }^{96}$ It may be that Pedro de Roda, who had links to both Conques and Toulouse and to the bishops responsible for the Romanesque basilica, had a role in facilitating contact with these sources. It is likely, too, that word spread that a great building enterprise was taking off in Compostela, and masons at sites where Romanesque was more advanced sought to take advantage of the opportunity. As work progressed the sources tended to remain the same, but the level of skill rose, as with the punishment of greed in the north transept, clearly based on

91 J. Williams, “Introducción”, El Beato de Osma. Estudios, Valencia, 1992, pp. 15-33.

92 Fletcher and Barton, World of El Cid., pp. 50-52. The only object that might be a gift of Fernando to the cathedral of Santiago is the so-called Cross of Ordoño II (S. Moralejo, in Santiago, Camino de Europa. Culto y cultura en la peregrinación a Compostela, Santiago de Compostela, 1993, pp. 269-270).

93 F. López Alsina, in Santiago, Camino de Europa, pp. 286-287; ReIlly, Reino, p. 84.

94 A. Gambra, Alfonso VI: cancillería, curia e imperio, I, León, 1998, no. 189, p. 483.

95 S. Moralejo, in Santiago, camino de Europa, pp. 288-289.

96 J. Williams, «'Spain or Toulouse?’: A Fifty-Year Perspective,» Actas del XXIII Congreso de Historia del Arte (Granada. 1973), I, Granada, 1976, 557-567, Fig. 566. 
the tympanum at Conques. ${ }^{97}$ It may be that, as work ceased or slowed at Toulouse and Conques, the first generation of minor masons was succeeded by their masters. At the same time these Gallic masons were joined by equally talented peninsular ones who had previously worked in Castilla and Aragón..$^{98}$ In the new church of Santiago we have a consummate witness to the initial blessings of royal patronage in the kingdom of León, but it would be a mistake to think of a royal building program. Initiatives were in the hands of entrepreneurial bishops like Diego Peláez, Diego Gelmírez and Pedro of Rodez.

Works sponsored by Alfonso's parents and his sister proclaimed their role as patrons by including effigies and names. That is a mode of patronage eminently aligned with their concern for dynastic stability and personal salvation. Alfonso certainly shared their goals, but he ruled in different times and led a kingdom that had grown beyond the Duero, and which had to absorb a burgeoning population and new economic and social realities. Strengthening the ties his father had initiated with Cluny helped, as did relations with Rome, essentially a new enterprise. Were we not ignorant of his initiatives in Burgos and Sahagún our portrait of Alfonso as patron might be strengthened, but probably not enough to invalidate the portrait of we have. A monk of Sahagún who would have lived part of his life under Alfonso probably was not far off the mark: varon por cierto en las cosas belicosas mui noble guerrero, en disponer bien su rreino proveido e discreto, en el juicio mui derecho, en los negocios seglares astuto e entendido, mas en las cosas eclesiasticas religioso e piadoso, en ensalçar y magnificar su reino mui singular. ${ }^{99}$ It would not have occurred to him to think in terms of artistic patronage, that activity being subsumed under cosas eclesiasticas religioso e piadoso. There is no hint that Alfonso's reign coincided with a surge in building that was unprecedented in the peninsula, at least since Roman times. It would have been impossible without the stability promoted by his success as warrior, judge and astute man of daily affairs, but others initiated and directed the building campaigns. Despite his reputation for piety and his personal record of bestowing treasures, Fernando was as active as his son in the Reconquest, and one may suspect that although his will and support were constant, the extraordinary range of patronage associated with the Leonese royal family was deeply indebted to his wife and daughter.

97 J. Williams, "Framing Santiago", Romanesque Art and Thought in the Twelfth Century. Essays in Honor of Walter Cahn, ed. C. HouriHane, Princeton, 2008, pp. 236-237, figs. 17-18.

98 S, Moralejo, "La primitiva fachada de la Catedral de Santiago", Compostellanum, XIV (1969), pp. 623-668 [=PAG. I, PP. 21-46].

99 A. Ubieto Arteta, Crónicas anónimas, p. 13. 